\title{
Women in the Twilight and Identity in the Making: The Concept of Transition in Eavan Boland's Poetry
}

\author{
By Marta Miquel-Baldellou \\ Universitat de Lleida, Spain
}

Poetry begins where certainties end (Eavan Boland. Battersby 1998: 2)

\begin{abstract}
Copyright (c) 2007 by Marta Miquel-Baldellou. This text may be archived and redistributed both in electronic form and in hard copy, provided that the author and journal are properly cited and no fee is charged for access.
\end{abstract}

\begin{abstract}
Eavan Boland's poetry often includes images denoting transition. The women that appear in her poems frequently undergo experiences of change and evolution. The transitional element which so often pervades Boland's poetry is rooted in her personal experience as an Irish woman poet. In her childhood, Boland underwent the journey from Ireland to England. As a mature and married woman, she moved from the urban Dublin to the suburban Dundrum. Having imbibed the poetry of canonical Irish male poets, such as W.B.Yeats, she had to struggle to find her voice as an Irish female poet. Moreover, once she was a mother, she also became aware of the intergenerational transition and the exchange of roles ageing implies. These transitional instances can be appreciated in her thematic series of poems "Suburban Woman" (1975), "Suburban Woman: A Detail” (1983) and "Suburban Woman: Another Detail" (2001). Throughout this series of poems, thematically united, but published in different collections, Boland depicts transition as embodied by the same woman portrayed on three occasions at different points in her life. A close analysis of this series sheds light on the transition Eavan Boland underwent as a poet and as a woman.
\end{abstract}

Key Words. Transition, liminal images, female voice, domesticity, ageing, diachronic analysis.

Resumen. La poesía de Eavan Boland a menudo incluye imágenes que denotan transición. Las mujeres que aparecen en sus poemas frecuentemente experimentan momentos de cambio y evolución. El componente transicional que se advierte en la poesía de Boland tiene su origen en sus vivencias personales como mujer y poeta. Durante su infancia, Boland abandonó Irlanda para irse a vivir a Inglaterra. Ya como mujer madura y casada, se trasladó del ambiente urbano de Dublín a los barrios residenciales y rurales de Dundrum. Tras haber descubierto la poesía, eminentemente masculina, de la pluma de poetas como W.B.Yeats, Boland tuvo que encontrar su propia voz como mujer poeta irlandesa. Una vez se convirtió en madre, tomó conciencia de la transición intergeneracional y el intercambio de roles implícitos en el proceso de envejecimiento. Estos ejemplos transicionales pueden apreciarse en la serie temática de poemas "Suburban Woman” (1975), "Suburban Woman: A Detail" (1983) y "Suburban Woman: Another Detail” (2001). A lo largo de esta serie de poemas, unidos temáticamente, pero publicados en diferentes colecciones, Boland describe el concepto de transición como personificado en la misma mujer, descrita en tres ocasiones diferentes a lo largo de su vida. El análisis de esta serie de poemas ilustra el concepto de transición que Eavan Boland experimenta como poeta y mujer.

Palabras clave. Transición, imágenes liminares, voz femenina, domesticidad, envejecimiento, análisis diacrónico.

ISSN 1699-311X 
Many of Eavan Boland's poems appear to be located at transitional or liminal moments. The women that populate her poems often tend to make their appearance at dusk, or during the twilight that is formed when the day gives way to the night. This atmosphere of ambiguity and of blurring of certainties seems to be particularly voiced through her poetry, and in a way, it reflects the uneasy position that the author felt compelled to occupy in relation to the traditionally male-dominated Irish poetry and provided a way to establish her own identity as an Irish woman poet.

The concept of transition in the poetry of Eavan Boland may be rooted in the physical and, by extension, psychological exile that she underwent when she was only a child. Having been born in Dublin, Boland and her family had to move to London, since her father was an ambassador. This journey at the tender age of six exerted a deep influence on the poetry she would write in the future. Being Irish in an English environment proved no easy task, and she experienced some anti-Irish feeling at the school she attended from a teacher who disapproved of her marked Irish accent. This incident brought Boland to an awkward position in an alien environment, and reinforced identification with her Irish heritage. These circumstances in the early years of the author also led her to become aware of the dichotomy between English and Irish identities, and influenced the transitional space between her homeland and England. This transition was physically performed by the journey which, despite being a source of conflict, also facilitated the latent formation of her poetry, and became a source of inspiration for Boland to write "An Irish Childhood in England: 1951” (Boland 1990: 107).

Another moment of transition, which deeply influenced her way of understanding poetry, took place when she moved from the urban setting of Dublin to the suburb of Dundrum once she got married to the novelist Kevin Casey. The physical change in locale from the capital city to a suburban environment reflected a change in her way of conceptualising poetry. She moved from the tradition dominated by male poets to which she had been indebted since her childhood towards the quest for a new voice that would be more in tune with her own new reality. Boland gained insight into the fact that the Irish poetry with which she had been acquainted through tradition did not offer any female image with which she could possibly identify. She realised that there was "a powerful tradition ... of the male poet. Irish poetry was male and bardic in ethos. Historically the woman is the passive object of poetry. We aren't supposed to write poems, we are supposed to be in them" (Battersby 1998: 3).

Gradually, this acknowledgment of "the growing distance between her own life and the women she saw reflected in literature" (Boyle 1996: 61) led her to elevate her domestic experiences; allowing them to become subject matter for poetry, by glorifying everyday household duties and establishing links with the experiences of other women whose voices had been silenced in the past. Her admiration for W.B.Yeats and other Irish male poets persisted and Boland decided not to take a separatist position. However, as Patricia Boyle mentions, "her real world, where honey sat on a kitchen table, replaced her borrowed Yeatsian vision” (Boyle 1996: 61). She could not help noticing the gap between the idealisations of women described in poems such as W.B.Yeats's "Red Hanrahan's Song About Ireland," featuring Cathleen ni Houlihan, or James Clarence Mangan's "Dark Rosaleen", which portrayed women embodying Ireland from a male point of view, and her own personal reality, which could also be extended to all other Irish women of her time. Eavan Boland began to feel the need to write about her own situation, to share her experiences with those of other women, trying to come to terms with her identity as a woman and as a poet; an identity which, in her poems, always appears to be in the making.

Another event that may account for this transitional component in Eavan Boland's poetry is the dual role the author had to undertake when she became a mother. The fact of being a poet and a mother at the same time seems to be a problematic issue that had already been considered by confessional poets such as Anne Sexton, Elisabeth Bishop and Sylvia Plath. Nevertheless, in Boland's case, motherhood proved a particular source of inspiration, which connected her to the experiences of other women that had also undergone similar experiences. Thus, her experiences of minding her daughters in a suburban environment led her to write in the 
margins of what was considered to be 'the subject for poetry', endowing her everyday and domestic experiences with transcendence, and introducing them into the domain of poetry, continuing the work of some female poets who had already raised their voices, especially Sylvia Plath, whose poetry enabled Boland "to establish some rich, shifting and shared boundary" (Allen 2002: 3). In addition, her concern with the need to perceive women as poets rather than as subjects in the poetry of male poets brought her closer to some feminist writers such as Denise Levertov and Adrienne Rich. However, the author asserted her position as a non-separatist, since she found herself unable and unwilling to become totally disengaged from a tradition which she had imbibed, even though she could not entirely identify with it. Thus, despite the attraction that the feminist movement held for her, Boland mentioned that "the imagination is an ambiguous and untidy place, and its frontiers are not accessible to the logic of feminism for that reason" (Schmidt 1997: 4); an idea which appears closely associated with the transitional aura with which her poetry is often endowed.

A further element that contributes to the definition of transition in her poetry is related to the author's personal conceptualisation of ageing. The poet, as a woman, underwent a period of transition from being a daughter to becoming a mother, and conversely, from being a mother to becoming a daughter again. ${ }^{1}$ In order to exemplify this exchange of generational roles, Boland makes a recurrent use of the myth of Ceres and Persephone throughout her poetry. In the Roman mythology, Ceres was the goddess of agriculture and was in charge of looking after the fields and the crops. However, Pluto, the god of the underworld, kidnapped Ceres's daughter, Persephone, and compelled her to live with him. As a result, Ceres suffered grief and despair due to the absence of her daughter. Meanwhile, in the underworld, Persephone ate seven pomegranate seeds; a fact that would have sealed her fate to remain in the

\footnotetext{
${ }^{1}$ The Irish contemporary poet Mary Dorcey also deals with this transitional exchange of generational roles implied by the process of ageing in her poetry, due to her personal experience of taking care of her ill mother.
}

felt towards her daughter impelled her to negotiate with Pluto and try to retain her daughter in her domain.

The outcome of this negotiation was that Persephone would remain half of the year with Pluto in the underworld, and the rest of the year with her mother on Earth. As a result, the seasonal cycle arose, since Ceres felt so griefstricken when her daughter was absent that she neglected her duty to raise the crops, thus creating the months of winter; and conversely, when her daughter was with her on Earth, her mother's joy was reflected on the fertility of the land, marking the beginning of the summer season.

What is relevant in this mythical recreation of the seasons is that Eavan Boland identifies with the roles assigned both to Ceres and Persephone. She sympathises with Persephone as a daughter, since the relationship that she had with her own mother seemed to be quite close, judging from the fact she describes her as "the friend of my lifetime" (Boland 1995b: front page). In due course, Boland herself also became mother of her own daughters who, in turn, due to the unavoidable process of ageing, grew up and distanced from her. Boland became aware of the fact that daughters can not only grow old but away ${ }^{2}$, and found herself playing the role of Ceres, trying to bring back her daughter from the underworld, when only some years ago she was still Persephone. This identification with both mythical personalities recurs throughout some of her poems, and proves particularly appropiate to describe her own situation, since as she herself admits in her poem "The Pomegranate", included in her collection In a Time of Violence, "the best thing about the legend is / I can enter it anywhere” (Boland 1995a: 184, 7-8).

By extension, this metaphor pursued by Eavan Boland to reflect on her own transitional rite of passage from being a daughter to becoming a mother can also be related to the transition that Irish women poets underwent from being objects in the poetry written by men to becoming poets themselves. Female Irish poets progressively abandoned the role of

\footnotetext{
2 Eavan Boland refers to this idea in her essay "Daughters in Poetry", included in Poetry Exhibits: The Academy of American Poets.
} 
Persephone, who had imbibed the seeds of pomegranate granted to her by Pluto; that is, they had been indebted to an eminently male tradition (represented by the pomegranate seeds), and had been metaphorically kidnapped by male figures to wander around the lines of the poems that only male poets were entitled to write. Women populated the poems of male poets as Persephone moved around Pluto's domain, like a goddess, but out of her own domain, and therefore, deprived of her own reality. They were set in an environment that was not theirs and found themselves under the rule of a male figure. In order to alter this situation of subjection, which granted them the opportunity of being subjects of poetry but subjected beings as well, there was the need of a voice to bring Persephone and, by extension, all those silent women, back to their own domain. This function was accomplished by Ceres who, by means of establishing a dialogue with Pluto, was able to reach a happy medium so that Persephone would remain both with Pluto (the male voice), and Ceres (the voices of the female poets). This quite closely resembles the situation in which Eavan Boland found herself when trying to reconcile the male-dominated poetry which she had imbibed as a student, with her own present-day female reality. Consequently, it seems that Irish women who intend to be poets need to face this duality when they confront the dilemma of deciding to write poetry.

These different ways of exposing the concept of transition can be perceived in the sequence of poems entitled "Suburban Woman" (The War Horse, 1975), "Suburban Woman: A Detail” (The Journey and Other Poems, 1983), and "Suburban Woman: Another Detail" (Code, 2001). The fact that these poems are thematically united but were published in different collections allows a diachronic analysis of the concept of transition at different stages, from historical to personal issues, through Eavan Boland's poetry.

The first poem in the series, "Suburban Woman", opens with a sequence of couplets whose form denotes a sense of duality. The poetic persona describes a nightmarish dream that hints at the ongoing conflict between Unionists and Republicans in Northern Ireland. This conflict is portrayed by means of contrasting images such as the dichotomy between the "town and country" (l.1), between the concept of "space" (1.2) and the walls that "began to multiply" (1.3), and the quiet "whispers" (l.4) and the violence of sexual "romperings" (1.5). The poetic persona describes this violent environment by means of images related to sex, and even describes it as a "proxy violation" (l.10), bringing a national conflict to the more domestic domain of the battle between sexes.

This nightmarish dream gives way to everyday reality in the following lines by means of another example of transition. The bedroom proves a transitional space between the world of dreams and that of reality. Inevitably, it seems that the female persona faces her own domestic war; her own battle with her household surroundings, and her personal struggle to dust the chairs and the carpet in a domestic locale. As we are told, she becomes "mistress of talcums" (1.21) and "courtesan to the lethal / rapine of routine" (1.23-24); phrases which endow this everyday reality with transcendence and glorify the concept of simplicity. By means of images related to the financial world, the poetic persona seems to be alluding to the myth of Ceres and Persephone, when she refers to "a seed, a life ransoming her death" (1.37); this line presumably points to the fact that Persephone ate the pomegranate seeds that necessitated the pact made by her mother and Pluto, which would ultimately lead to the creation of the seasonal cycle.

Once the reference to a mythical dimension has been made, the poetic persona leaves her house for the garden at another transitional moment. If we firstly have attended to the temporal transition between the night dreams and the reality implied by the morning sun, now the reverse transitional moment from daylight to dusk is described. The lines depict how the "sunlight shifts like a cat / burglar, thieving perspectives, leaving her in the last light / alone" (1.40-43). In the midst of this twilight, she contemplates the vision of the knapweed which resembles her own life, "falling with her flowers" (1.48), in a possible reference to her own transitional phase of ageing. Once she returns to the house, it seems her working day has come to an end, although it is mentioned that now it is her turn to write; "now she will shrug / a hundred small surrenders off as images / still born, unwritten metaphors, blank pages” (1.52-54). These lines 
corroborate the dual nature of the poetic persona as a mother and as a poet, and seem aimed at establishing links with those women of the past who were unable to pursue the poetic role, and were only allowed to fulfil that of being mothers. This link with other female voices contributes to defining the concept of transition from the past to the present moment, and enables us to perceive the changes that have been proceeding until the present situation.

The second poem of the sequence, "Suburban Woman: A Detail" opens with some lines that denote a sense of order; a sense that everything is in its proper place, and that all elements seem clearly cut since "the shrubs are prinked, the hedges gelded" (l.3). However, from these lines of order and tangibility, the poetic persona goes on to describe how the cars coming from Dublin approach the suburb of Dundrum. In this case, some dichotomies are established in the poem between the surrounding darkness and the headlights of the cars, and between the high mountains in the south of Dublin and the valley where Dundrum lies. These dualities reach their conclusion in the transitional transformation of the tangible elements mentioned once they are filtered through the imaginative mind of the children, who thought those car headlights "were stars" (1.6).

Once this transcendental element has been introduced, the second part of the poem becomes endowed with a mythic dimension, since the author again seems to be alluding to the myth of Ceres and Persephone. The poetic persona reflects on the transition from being in company with her daughter, to the state of remaining alone, since she states "Winter will be soon" (1.13), which is the season when mother and daughter become separate from each other. As happens in her later poem "The Pomegranate”, Boland plays the roles of Ceres and Persephone at the same time, implying the dual and transitional exchange of roles due to the passage of time.

In the third part of this poem, the action is brought back to Dundrum, where we are presented with a woman walking towards one of the houses in the neighbourhood. We are told she is "blended in / by the last light" (1.2122), in clear reference to this recurrent twilight, which makes possible the blurring of details by means of which the appearance of transcendence is ensured. On this occasion, this woman is granted a voice, and she reveals her determination to start. In this case, we are not told what she intends to start, because what really seems to matter here is her resolution, that is, her confidence to begin something from nothing, to establish a tradition of her own. However, despite this determination, the contours of the elements around begin to lose shape, and it is mentioned that the light was "lessening, / the hedge losing its detail, / the path its edge" (1.25-27). Subsequently, once the twilight brings about this atmosphere of uncertainty, the poetic persona finds a way of coming to terms with her identity. In the midst of the background of nature, she finds a tree endowed with magic powers, which could be interpreted as representative of the genealogy of all those women who were deprived of their right to speak; this reading seems plausible since in the last line of this poem the tree seems to raise an elegiac voice "crying 'remember us"' (1.42). Again, we attend to this blending of past and present times, when the poetic persona brings back all those voices that were not allowed to be raised, all those female writers that were never listened to.

Similarly, "Suburban Woman: Another Detail" opens with a scene which locates at dusk the actions described in the poem, that is, at the transitional time which separates the day from the night. The neighbourhood, being a physical locale, is described in terms of its colour, which is "the color of shadow / the color of tone" (1.3-4), a greyish atmosphere that endows the setting with ambiguity. Once the action has been generally located in terms of place and time, the poetic persona describes herself at her desk, imagining. Another duality is established between the external locale that has been described so far, and the cosy and warm atmosphere that one can infer with regard to her desk. This opposition between the external and internal settings is reinforced by the fact that it is mentioned that the subject is imagining the "wintry air" (l.6), which leads us to presume she is not in touch with the cold, since she is only able to imagine it. Another duality to add is that which is implied in the following lines of the poem, in which the poetic persona remembers herself taking care of her daughters when they were still children. One could relate this duality between her present self and her past self, who stands in a 
way for her alter ego, to the figure of the doppelgänger. This double figure serves the purpose of bringing together the woman that minded her daughter and the lonely woman that she is now, since her daughter has already grown up and away. By extension, this duality is reflected in the couplet form given to the lines describing this event: "another woman is living my life. / Another woman is lifting my child”. (1.9-10) This blurring of personalities is reinforced in the next stanza by the elision of the subject, which leads us to wonder who is really carrying out the everyday household chores of peeling a lemon or putting a child to bed.

All these dualities and ambiguous descriptions seem to find their resolution in the following lines of the poem. The poetic persona states that "the child she lifts again and holds / are all mine" (l.17-18), which proves the interpretation that the woman she is imagining is actually the woman that she was in the past, in other words, she is indulging in the memories of her past. Moreover, she also finds herself reflecting on this transition from being a mother minding her children to being alone. Her memories bring her back to a moment in the past, when her past self looked at the future, which is presented in the poem by means of a "road / in the featureless November twilight”. (1.21-22) Again, it is possible to notice the recurrent use of elements that are contrasted, or the inclusion of terms that denote ambiguity. This is the case with "featureless", which implies the fact there is no tangible contours to provide a clear definition, which in turn could be related to the concept of identity held by Eavan Boland which is defined as inherently transitional. This sense of uncertainty is also implied by the fact the action is set at November twilight; the month of November usually implies connotations of mourning, since the year comes to an end, and if we add to this the fact that the scene is set at twilight, we are presented again with a transitional moment that will give way to the present moment of reflection, where the present self is located. Thus, in the second part of the poem, the action moves back to the present moment, and this is emphasised by the change in the subject person from 'she' to 'I'. The poetic persona acknowledges the fact that she finds herself writing at her desk alone, which contributes to endowing the poem with a circular structure, since the first lines also referred to the act of the poet's being at her desk. However, one may find a slight difference between the two acts described, which consists in the fact that at the beginning of the poem, the poetic persona was imagining at her desk, whereas in the last lines of the poem, the poet asserts she is writing at her desk. This other paradigm of transition can be extended to those Irish female poets that were silenced and could only resort to the world of imagination. They could only imagine that they could write, whereas the present-day female writers at least can cling to their right to raise their voices. It is also important to notice the last lines of this poem, which reveal some features of the commitment of Eavan Boland's poetry to writing about her own domestic experiences, that is, those experiences which, as she says, are "close to the bone" (1.33).

Bearing in mind this sequence, one may attempt to trace the transition that occurs throughout these three poems. The use of the pronoun "she" turns into "I" in the second poem, and gives way to the duality between "she / I" in the last poem of the sequence, thus marking the transitional movement from being a spectator to becoming the central character in the poem, and therefore, identifying with it. Similarly, the rhythm moves from the quick cadence of run-on-lines to the slow pace implied by the profusion of self-contained lines in the last poem of the series. The transition in terms of the pace of the poems also echoes their tone, which moves from a harsh one related to warfare to a peaceful one associated with an evening in a garden. The form of the poems proves also divergent; the use of the couplets in the first poem of the sequence implies that form had a major relevance, whereas in the third poem a free form, exemplified by blank spaces and indentation, seems to be dominant. The images used throughout the poem seem to vary in a slight degree, since in the first poem, the poet makes use of some imagery related to warfare together with domestic images, whereas in the second and third poems, images related to domesticity clearly take precedence. One could also add to these features of transition or evolution throughout the sequence, the length of the poems itself, which tend to become shorter in the later poems; this may be interpreted as a sign of the poet's being closer 
to finding her own voice, and her concern with bringing her domestic experiences into the domain of poetry.

Taking into account all these instances of transition and ambiguity, the poet tries to search for her identity in locations and temporal settings whose contours are blurred, because she feels it is there that identity is more likely to be formed. Throughout her poetry, she attempts to find her voice and position in a tradition which proved eminently male-centred, and in which women appeared as objectified idealisations to become myths. They were sung about, but they were never granted voices to achieve their own singing. Eavan Boland's concern with finding her identity as a woman poet seems to voice the awkward situation undergone by other Irish female writers who were never granted the opportunity to speak. As Patricia Boyle states Eavan Boland's "poetry records a process of self-definition that transcends the boundaries of her personal life" (1996: 59) to establish links with past female generations, implying thus both a personal and generational transition which echoes the end of certainties, gives way to a new poetry and indicates the path towards finding her true identity.

\section{Works Cited}

Allen Randolph, Jody. 2002. “A Backward Look: An Interview with Eavan Boland.” Interviews with Eavan Boland. WebGuild. Carcanet Press Ltd. 2002. 1-8.

Battersby, Eileen. 1998. "The Beauty of Ordinary Things.” The Irish Times. 22 September. 1-5.

Boland, Eavan. 1990. "An Irish Childhood in England: 1951." Outside History: Selected Poems, 1980-1990 . New York: Norton. 107. . 1994. In a Time of Violence. London: Norton. . 1995a. Collected Poems. Manchester: Carcanet. . 1995b.Object Lessons: The Life of the Woman and the Poet in Our Time. London: Norton. .1997. "Daughters in Poetry." Poetry Exhibits: The Academy of American Poets. 1997-2006. http://www.poets.org/viewmedia.php/prmMID/17142

Boyle Haberstroh, Patricia. 1996. “Eavan Boland.” Women Creating Women: Contemporary Irish Women Poets. New York: Syracuse UP. 58-90.

Schmidt, Elisabeth. 1997. "Where Poetry Begins: Eavan Boland in Conversation." Poetry Exhibits: The Academy of American Poets. 1997-2006. http://www.poets.org/viewmedia.php/prmMID/15939 